JAY HOECKER, DEB BERNAL, ALEX BRITO, ARDA ERGONEN, RICHARD STIFTINGER

\title{
THESE MODELS NEED ENTERPRISE DATA MANAGEMENT! ${ }^{1}$
}

The current data management systems for the life cycle of scientific models needed an upgrade. What technology platform offered the best option for an Enterprise Data Management system?

After 28 years of public service, the Information Technology Bureau Chief for the Southwest Florida Water Management District (SWFWMD), Dr. Steven Dicks, was still passionate about serving the public. By first focusing on the needs of people in the District, Dr. Dicks was able to objectively observe the many aspects of operations for which he was responsible. His observations led him to believe that the use of technology within his organization wasn't as effective and efficient as he knew it could be.

The SWFWMD managed the water resources of 16 Florida counties in an area that was close to 10,000 square miles, with 4.7 million inhabitants. To effectively manage water resources, the organization needed to understand current water needs, prepare for future needs, and protect and preserve water resources within its boundaries. A significant part of managing water resources involved the production and utilization of scientific computer models that help track, predict, and control a plethora of water related challenges. At the SWFWMD, individuals used desktop computers to run most of the scientific models. Given the limited computing capacity of the average desktop computer, running a model was beginning to require too much time; and simple interruptions, such as a system reboot, could jeopardize the ability to complete long model runs. Therefore, the resulting data used and produced was often very ineffectively managed.

Dr. Dicks began to wonder about the current system of producing and managing scientific models, and how the systems might be improved. He evaluated options. He thought upgrading individual desktops could help, but only in the short term because as the data sets and demand for processing power continued to grow, the desktop might always be a step behind. Installing powerful servers to house the data sets and run the models would be a significant improvement, but the cost to acquire and maintain the new system might challenge the budget. A cloud-based solution utilizing an "infrastructure as a service" approach, was a third option, but current system infrastructure compatibility, security, and access needed to be carefully evaluated.

Dr. Dicks believed that data management was just as important as the processing power of an upgrade, and that ultimately the technology that allowed for the most effective EDM system needed to be identified and implemented to best serve the needs of the District into the future.

\footnotetext{
${ }^{1}$ Copyright (C) 2017, Muma Case Review. This case was prepared for the purpose of class discussion, and not to illustrate the effective or ineffective handling of an administrative situation. Names and some information have been disguised. This case is published under a Creative Commons BY-NC license. Permission is granted to copy and distribute this case for non-commercial purposes, in both printed and electronic formats.
} 


\section{Water Resources}

\section{Federal}

Management of water resources occurred, for the most part, at the state level. However, federal/state cooperation was essential to achieving a well-balanced approach to managing the nation's water. The Environmental Protection Agency (EPA), the United States Army Corps of Engineers (US ACE), and the United States Geologic Survey (USGS) all played a role. The Army Corp had historically been involved in dredging waterways as well as building infrastructure (http://www.usace.army.mil/About.aspx). The USGS played a critical role collecting and disseminating reliable, impartial, and timely information (Water Resources of the United States, 2014). The US EPA focus was primarily on protecting the nation's water resources as it pertained to water quality. Federal agencies such as the United States Department of the Interior and United States Department of Agriculture also had some level of involvement.

\section{State (Florida)}

The Florida Department of Environmental Protection (FDEP) was the primary agency in the state for environmental management (http://www.dep.state.fl.us/mainpage/default.htm). FDEP coordinated among a diverse group of agencies in protecting the state's land, air, and water resources. FDEP had four areas of responsibility: 1) water policy and ecosystems, 2) water quality assessment and restoration, 3) permitting, compliance and enforcement, and 4) financial assistance. FDEP, in turn, delegated much of its "general supervisory authority” in terms of water, to the state's five water management districts (see Exhibit 1).

\section{Water Management Districts (Regional)}

Water management districts were delegated authority by FDEP via Chapter 373.4131, F.S. to administer water management at the regional level (http://www.dep.state.fl.us/secretary/watman/default.htm). Each of the five districts had a defined boundary that was primarily based on watershed basins. In the case of SWFWMD, the jurisdictions included Citrus, DeSoto, Hardee, Hernando, Hillsborough, Manatee, Pasco, Pinellas, Sarasota, Sumter, and portions of Charlotte, Highlands, Lake, Levy, Marion, and Polk counties (see Exhibit 7). This was an area of nearly 10,000 square miles with 4.7 million people (Who We Are, 2014). A list of all the districts and their jurisdictions can be found in Exhibit 2. By statute, FDEP provided the following direction to the districts:

Pursuant to these delegations, the districts were authorized to administer flood protection programs and to perform technical investigations into water resources. The districts were also authorized to develop water management plans for water shortages in times of drought and to acquire and manage lands for water management purposes under the Save Our Rivers program. Regulatory programs delegated to the districts include programs to manage the consumptive use of water, aquifer recharge, well construction and surface water management. As part of their surface water management programs, the districts (except for Northwest) administer the Department's storm water management program. This law also increases the districts' contacts with local governments by directing the districts to help with the development of the water elements in local government comprehensive plans ("Water Management Districts," 2014).

\section{Local (Cities, Counties \& Utilities)}

Cities and Counties were arguably more intimately involved with management of water resources. Utilities, which developed and utilized water for public consumption, were charged with responsibly developing this supply without adverse impacts to the environment. Local governments also managed storm water systems, monitoring water quality, and ensuring natural systems remained intact. 
MUMA CASE REVIEW

\section{Southwest Florida Water Management District}

\section{Areas of Responsibility (AOR)}

SWFWMD was established in 1961 as an agency to address flood protection with four areas of responsibility (AOR): water supply, water quality, natural systems, and flood protection. The District employed roughly 574 full-time employees (see Exhibit 3), and was funded primarily with ad valorem dollars through property taxes. A millage rate was set annually that determined the District's budget. For additional information on how the District was funded and how funds were allocated in the 2014-15 budget, see Exhibits 4 through 6. For more on SWFWMD's mission and four AORs, see Exhibits 7 and 8.

\section{Scientific Models}

In order to support these four AORs, SWFWMD developed and utilized a diverse set of scientific models to help better understand issues facing water resources in the region. In its simplest form, a scientific model could be described as a predictive reflection of reality. At SWFWMD scientific models provided the ability to evaluate the potential impact of natural or human events on water resources. Depending on which model was being used and how it was being used, it might have addressed one or multiple AORs (Dr. S. Dicks, personal communication, 2014).

The spectrum of scientific models deployed by SWFWMD could be quite diverse, with approximately 36 different models requiring an array of IT support and infrastructure (see Exhibit 12). For example, the District-wide Regional Model (DWRM) was a three-dimensional groundwater simulation system that functioned as support for regulatory evaluation of water use permit applications. DWRM was one of the more frequently used models, with an average of 3000 annual runs, and an average run time of less than five minutes with an input file size of $50 \mathrm{MB}$ and an output file size of $250 \mathrm{MB}$.

The Interconnected Pond Routing Model (ICPR2D) was a two-dimensional surface model that aided SWFWMD in evaluating large-scale interactions of water resources, alterations, restorations, public education, and resource management for a 2000 square mile watershed. Although the annual number of runs was just 100 times per year, the average time to run the model was five days on a super computer and 30 days on a high-end desktop. The input files themselves were $76800 \mathrm{MB}$ per run with an output file of 71680 MB (Dr. S. Dicks, personal communication, 2014).

These models put significant demands on the IT infrastructure at SWFWMD. The Information Technology Bureau had the responsibility of managing these demands, and procuring services to address the district's IT needs. The Information Technology Bureau supported the District's mission and its AORs by providing the daily operational support necessary for the District to carry out all of its strategic initiatives and core business processes. The many responsibilities included the procurement, maintenance, and operation of database management systems, operating systems, servers, storage, personal computers, telecommunications, video conferencing, and network infrastructure (Dr. S. Dicks, personal communication, 2014).

SWFWMD scientists and modelers used data such as water quality, flows, and levels that were collected by field staff or real-time data acquisition systems. Modelers then utilized specialized software to perform quality assurance and to look for anomalies in the data. The quality-assured data was then transferred to a series of federated data warehouses residing on SWFWMD's enterprise database servers. The modelers then downloaded data required for their models to their own desktop computers. There was often some 
level of reformatting and/or pre-processing done on the data prior to loading it into a model. Depending on how large the data set models were, it could take from a few minutes to several hours or days for each iteration. In addition, if there were interruptions when the model was running, then the time to complete the output increased, as the model needed to re-run to ensure its quality and validity.

In some instances, where the models were too large to run off PCs, and more processing power was required, SWFWMD used third parties. These third parties not only possessed more power in their PCs, but also had a well-established set of processes and culture where data was actively managed. At the time of the case, SWFWMD owned two server farms in Tampa and Brooksville. Installing new and more dedicated servers for running models was considered a viable option. The organization had already researched possible servers for acquisition. The cost was expected to be around \$30,000 per server with up to ten servers being purchased to support modeling efforts (see Exhibit 11).

As the input data continued to grow, more processing power from new servers was critical. The scientific models ran efficiently on servers, and the server system enabled a common storage location for the resulting data. The common storage location feature of organizational server systems was useful to an EDM strategy. Buying new, dedicated servers to meet computation and data storage needs was also a relatively straightforward process with a comparatively low effort requirement. The output files of the scientific model computations were quite large, and could go up to 358 GB per run. There were 36 different models with different runs annually (see Exhibit 12). The data collected and the network of data input points used to run the scientific models was growing every day. As Dr. Dicks said:

...the technology part was easy, I can buy all the horsepower I need to run these models, but it is a well-established knowledge management process to organize and manage the data that is most important. We've brought on a lot of new modelers who bring new challenges and methods. We don't want to smother them with process, but we need to find a better system to manage the modeling work being done.

\section{Data Management}

Organizations that study data-intensive issues, like hydrology, wastewater, and storm water utilities, collected an enormous volume of monitoring data. These organizations spent a large amount of their budget and manpower on monitoring for water quality, water flow, and infrastructure to support their primary agency tasks--especially those in planning, regulatory compliance, and predictive modeling (see Exhibits 5 and 6). Most water management districts purchased a suite of software products or services to support their data infrastructures. SWFMWD used an Oracle-based platform for data management and ESRI for capturing GIS-tagged data in the field.

SWFWMD's collection of data spanned several data sources, including water systems, network information, field work orders, field gauge results, uploaded telemetry data, and modeling results themselves. The complexity of having so many data points and data processing demands inevitably placed a great focus on the agency's data management and distribution. For SWFWMD to derive executable insights from so many touch points using its ESRI-fed Oracle database, it was imperative to achieve an integrated, common platform for accessing and/or reporting all of its data. Paul Barth described how the business architecture typically defines the business core data capabilities as "capturing and creating data, cleansing and organizing it, and then mining its ecosystem...the business and technology capabilities together created the 'data ecosystem'” (Barth, 2014). 
An integrated data management system could also be tied into other business features like visualization and mapping features. All of these factors could assist in tracking and analyzing trends that might have anticipated and altered future demands on water resources and/or water management issues. Moreover, these features enhanced the decision process by providing a broader and more holistic view of the water system network.

\section{Organizational Data}

Solutions for some complex organizational challenges might be found within data sources. Often these data sources at SWFWMD were growing at an exponential rate. Authors Amit Pandey and Sushma Mishra explained, "In the era of big data, organizations today rely on a huge quantity of data from diverse sources and need to integrate this data in a speedy manner to gain any strategic advantage out of the data" (Pandey \& Mishra, 2014). How could SWFWMD manage this large amount of data? Some thought that an organization like SWFWMD should centralize its data resources, thereby enabling better access to its databases across the organization. Inevitably, SWFWMD struggled to extract, analyze, and communicate data and trends across the organization and to its external users.

In an InformationWeek article, Rajan Chandras shared a similar concept by stating, "Your insight into data is incomplete without your insight into the people that manage, consume, and influence data" (Chandras, 2011). The discussion turned to how SWFMWD would extract relevant data and communicate this information across its units and even within its data-modeling unit. This effort demanded a change to the work process flow and the surrounding culture. This shift might have also required additional training and/or incentives to motivate the adoption of a single data management system; and a reinvestment of time, management tools, and strategies to increase the usage of that system (Dr. S. Dicks, personal communication, 2014).

Getting everyone onboard in using a data management system had its own set of tasks and strategic initiatives that helped to evolve the organizational culture to increase data sharing, and especially, a willingness for developers to share results was crucial. This was particularly important for SWFWMD's data-modeling related tasks.

Many experts supported the implementation of a data management system. They noted that improving one's data management services typically led to the interconnection of dispersed or seemingly irrelevant data, and then transformed the data into unified, actionable information. In Paul Barth's diagram (see Exhibit 4), a management system integrated throughout varied departments had potential to provide several cross-functional advantages. Another IT service consulting company, GENPACT Headstrong, demonstrated in one of their illustrations that these advantages were known to benefit many business functions (see Exhibit 9).

These advantages included:

- Business intelligence (data mining and data warehousing).

- Enterprise data management (EDM), or enterprise information management (EIM).

- Master data management (MDM).

- Performance technology and life-cycle design (see Exhibit 9).

At SWFWMD, Dr. Dicks focused on the EDM component of such an approach. Without implementation of an EDM system, Dr. Dicks felt that data sharing would be limited between SWFWMD's traditional 
department silos. As Pandey and Mishra (2014) wrote, "Though these silos might help in quick querying capabilities, the efficiency for the overall enterprise was compromised...” EDM should allow the delivery of data results across multiple systems and applications.

\section{Enterprise Data Management}

An EDM system was a company's management strategy for its "structured" data across various business units, processes, and software systems. The data strategy was implemented from the original data-entry point to its utilization (i.e., producing a report or data model). A strong feature of an EDM system was its ability to provide a unified solution across business units. "Enterprise data management provides a single view of the truth, unique reference data and a unified data quality framework to integrate, validate and migrate data” (Pandey \& Mishra, 2014). This was critical in order to circumvent data mismanagement and maintain data quality.

The end goal was to create a sustainable EDM system with a high degree of trust for its data quality. For SWFWMD to achieve a sustainable system, both its business and IT frameworks required an improved approach on data governance (i.e., policy, rules, and data quality). The Enterprise Data Management Council (EDM Council) offered an integrated approach to review some of these requirements. The EDM Council was founded in 2005 by the financial industry as an unbiased business forum looking to promote efficient business operations through data management mandates. The EDM Council compiled a list to outline eight analysis capabilities called the Data Management Capability Model (DCAM) ("Data Management Capability Model (DCAM),” 2014). The four DMCM analyses mentioned below applied directly to SWFWMD’s discussions:

- Data Governance helped to define an operating model, especially with regards to the establishment of a control environment, and additional alignment mechanisms such as (enforced) group norms, policies, and workflow process standards.

- Data Quality referred to the concept of fit-for-purpose data, and the processes associated with the establishment of both data control and data supply chain management.

- Data Operations defined the data lifecycle process, and how data content management was integrated into the overall organizational ecosystem.

- Technology Architecture addressed the relationship between the IT infrastructure, and its ability to integrate with one or more databases for operational deployment.

A visual graph by the service-based company, ITC Infotech, further illustrated several benefits available from EDM, including the integration of internal ERP/CRM and other external capabilities (see Exhibit $10)$.

One of the keys to a successful EDM system was its data governance. With EDM, an internal group devised a set of operational rules--sometimes referred to as "business" or "golden” rules. These rules supported organizational policies and guidelines that were used to manage its data input, process storage, and other operations (http://www.edmcouncil.org/). In his book Enterprise Knowledge Management, David Loshin explained that EDM was part of an organization's knowledge management function. He states, "Business operations were defined using a set of rules that affect everyday execution. When the business depends on the correct flow of information, there was an aspect of data quality that intersects the operational specification” (Loshin, 2001). These policies and rules were imposed to deliver consistent and accurate data across business units, and to adhere to time-sensitive elements or regulatory demands. Along with the added control of rules, EDM solutions could help SWFWMD to improve internal workflow processes, productivity, and compliance. 


\section{Data Management Implementation}

To achieve success with an EDM system, SWFWMD should strive for a level of "workflow" alignment among its staff, subject matter experts, departments, and vendors. The process of data governance and related operational rules helped to create alignment or agreement. Additionally, no longer would one individual own the data as it would be used cross-functionally (Pandey \& Mishra, 2014). However, the implementation of EDM at SWFWMD could be difficult because it also required a cultural shift within the organization, and the positioning of its adoption as an agency priority. Without buy-in from SWFWMD staff, the described barriers would cause resistance to the implementation or adoption of a new data management system. The implementation of a data management system proved to be more culturally-driven rather than just a technology problem. In fact, as Dr. Dicks could attest to during previous attempts, focusing on a technological solution without applying changes to the agency's culture failed to produce successful results (Dr. S. Dicks, personal communication, 2014).

The ultimate goal for developing a data management system was to build an interoperable, data processing environment. However, the reality of completing such an endeavor would probably take both a strategic and tactical approach through incremental stages and span several years.

How would the current model developers and users react to process changes? Contemplating the tasks involving organizational change, Dr. Dicks felt he would need to find a person with the leadership style that best matched the organization's culture to lead the process, especially when addressing changes to workflow processes and/or implementation of an EDM system. In efforts to reflect inclusiveness and accountability, this individual should probably be internal with external consulting support to the agency. This might have assisted in addressing the deeply-embedded cultural issues or resistance to change seen within many organizations.

But what about the other looming decisions to create improved efficiencies? Which hardware solutions offered effective data management for housing, processing, and utilizing scientific models? What EDM systems had staying power and could serve well into the future?

\section{The Options}

1. Do Nothing: SWFWMD had made relatively unsuccessful efforts in the past to move towards knowledge management procedures. Should SWFWMD continue these efforts to help change the culture of the organization by making EDM a top priority?

2. Upgrade the Existing PCs: This option offered many short-term benefits. Would upgrading the existing PCs also be able to provide a sustainable EDM strategy?

3. Installing More Powerful Servers: SWFWMD currently had their own dedicated servers where data for the scientific models was collected and stored. Installing more powerful servers would make data storage more efficient, and the data center had adequate resources to handle new servers.

4. Infrastructure as a Service (IAAS): Cloud-based computing offered an attractive longterm solution. The district had seen certain information systems within their district successfully move to the cloud. The biggest concern was how to integrate existing systems with cloud vendors. How would data security and availability be affected? 
HOECKER, BERNAL, BRITO, ERGONEN, STIFTINGER

As the data sets continued to grow, the processing power needed to support these models, and the amount of time needed to run the models to produce an output would significantly increase. The current system used to produce and manage data and scientific models should be improved. SWFWMD had seen other water management districts become more effective in the way data was stored and managed. Dr. Dicks was uncertain about which direction to take.

\section{Upgrading PCs}

Dr. Dicks and his team were evaluating options for the best PCs that would fit the needs of the modelers. With more memory, more storage, and high-end integrated graphics these PCs would be able to support the rapidly growing data sets and decrease the amount of time needed to run the models.

\section{Advantages to Upgrading PCs}

Dr. Dicks described PCs as “a well-known and relatively inexpensive technology.” From the end user's perspective, they retained control of how the models were run and used. Scientists and modelers liked to have a certain amount of control in how the models were run. There were models run at SWFWMD that required integrated graphics cards or physical software licensing dongles on desktop PCs. The option of upgrading the existing PCs would be easier to implement and support these models. Additionally, upgrading the PCs would be a relatively quick process.

\section{Disadvantages to Upgrading PCs}

This option was viewed by Dr. Dicks as a short-term solution that would last approximately two to three years. The issue of data loss, if PCs were to crash without sufficient backup, was a big concern. Individual computers would continue to make it difficult for any data management processes to establish a chain of custody and consistency in data management.

\section{EDM in Upgrading PCs}

Scientists and modelers liked to have direct access to their PCs, but were not using them to their full capability, as they only spent a fraction of the time running models. Dr. Dicks saw this as a big inhibitor to an effective EDM process, as other staff could use the PCs in the interim. In an EDM system, individuals do not own the data. There was a culture issue because PCs provided the model makers and scientists with the ability to structure and retain data however they saw fit. This created an environment where data was not consistently managed in an effective manner, and would be challenging for implementation of an EDM system on desktop PCs. Furthermore, this culture created difficulties with succession planning. As individuals retired or left the district, how could their work be documented so that their knowledge was not lost when they left?

A potential resolution for these issues could be the application of data governance practices. An EDM system could offer data governance, which would require standard practices in the collection, identification, storage, and usage of data. By having data governance, model makers and scientists would structure and store data in a way that was consistent in the organization. This would allow for knowledge to be maintained as individuals left the organization (Smith, 2007).

Upgrading the existing PCs would provide a short-term solution to the issue of the limited computing capacity needed to support the rapidly growing data sets. However, Dr. Dicks was equally concerned with how the data that was produced was then also stored and managed. Furthermore, he believed that knowledge, culture, and mindset all had to come together in order to establish EDM procedures. Dr. 
Dicks said, "The decision on whether PCs should be purchased was dependent upon cradle-to-grave modeling workflows. We were currently working with the modeling community to identify and improve workflows” (Dr. S. Dicks, personal communication, 2014).

\section{Upgrading Servers}

\section{Advantages of Upgrading Servers}

Installing new servers could be an easy solution for SWFWMD, and might not require the staff to change the computation for scientific models. The workload of staff should not increase significantly. It was practical for the district to purchase and install new servers, and continue working with these servers with an approach similar to the present system.

Another advantage was related to the issue of security. The servers would be housed in a secured data center where physical and network activity could be tightly controlled. This allowed for the implementation of processes (such as patch management) that would not hinder long model runs while ensuring that the systems were secure from malware. This coupled with controlled data management practices ensured that the data produced by SWFWMD scientific models was available to the public. However, it was extremely important that the data was not manipulated by external users. Furthermore, the data was regularly backed-up in the server environment. Even if the servers were damaged in a natural disaster, for example, there would be backup files.

Primarily because of advances in server technology that lowered power usage, the new servers would also have less power consumption (Velte, Velte, \& Elsenpeter, 2009). The district's data center facilities had the current physical infrastructure to accommodate additional servers, and cooling and electrical systems that required little change.

\section{Disadvantages of Upgrading Servers}

There were some disadvantages of using an in-house server approach for modeling. The District's standard life cycle for servers was five to eight years. However, Dr. Dicks estimated that because of increased computational demands by modeling software, the effective life of the servers was about three years. This would require that modeling servers be repurposed to less demanding jobs, and that new, more powerful servers would then be purchased to support modeling tasks. This re-purposing of servers represented an increased workload on IT staff.

Another issue was related to the queue process for running scientific models on the servers. Installing too few servers could lead to long queuing times to run the models, and installing too many servers could lead to underutilization of resources. It was anticipated that models would be run in a virtualized environment. While this gave the modelers more control over their environment, it would also require that modeling staff be trained in and take on the responsibility of managing the virtual environment.

Lastly, some models might be tightly coupled with graphics displays, requiring special licensing hardware keys, or might need to be run in conjunction with other software originally designed for use in a desktop environment and therefore, might be difficult to implement on servers. 


\section{EDM in Onsite Server Systems}

Dr. Dicks believed that enterprise data management processes would still be required in a server environment. Just installing new servers might not be enough to solve the data management problem. There should be an enterprise approach for data management.

It was likely that the existing server process used for collecting and managing scientific data could serve as a model for developing an approach for managing model data. There were also approaches used by other water management districts that could serve as examples. Developing EDM on in-house servers would require gathering input from modelers on how they did desktop work, and then adapting these processes into SWFWMD’s environment.

Dr. Dicks believed that it was easy to purchase and install new servers. The hard part was to have an understanding of knowledge management of the models. SWFWMD had the infrastructure to relatively easily implement a server upgrade solution. Dr. Dicks proposed the following question, "Was it possible to have an effective data management solution in an upgraded server environment, or should he consider other options, such as cloud based solutions?”

\section{Infrastructure as a Service (IAAS) - Cloud}

As defined by PCMagazine.com, "Cloud computing means storing and accessing data and programs over the Internet instead of your computer's hard drive” ("What Is Cloud Computing?” 2014). The definition could also be expanded to include "your" servers. An option with cloud computing services (see Exhibit 13) was Infrastructure as a Service (IAAS), and IBM.com described IAAS as a way of renting servers, data storage, and networks in the cloud on a pay-as-you-go basis (Velte et al., 2009). Given the growing data collection process of SWFWMD, and the growing network of data input points, as well as the organizational need to manage the data of model production, was IAAS a viable solution? Was one aspect of IAAS, such as data storage, the best option?

\section{Advantages of IAAS}

Unlike PCs and onsite servers, IAAS offered SWFWMD a certain level of flexibility for running scientific models that was unique to cloud computing. The flexibility was related to the pay-as-you-go approach. In using IAAS, as opposed to using PCs and servers, the cost associated with running scientific models was due to computer processing time. As an example of the pay-as- you-go model, Exhibit 14 shows the cost breakdown from an IAAS vendor. With PCs, the cost of the system was sunk cost that was paid regardless of the level of usage or model processing time. With an onsite server system, the cost was constant, as the servers were kept online for remote access by the model developers, even if there were no models being run.

IAAS also offered on-demand processing power. In an onsite server system, scientific models queued up to use the processing power offered by the infrastructure. Depending on the complexity of the models, the queue could be very long. IAAS providers had vast server farm systems that provided processing power as needed. This would tend to reduce the queueing problem for scientific model running. This power ondemand also facilitated scalability. As SWFWMD data grew and the scientific models processed more information, IAAS systems would have the capacity to accommodate growing processing power needs.

IAAS also offered access from anywhere and anytime to the meta-data for running models, as well as to the models after they were produced. Models and data on PCs were only accessible to the individual user. 
In-house onsite servers offered the same flexibility as IAAS when it came to access, but as mentioned before, they required constant online availability, which might not be cost effective.

Cloud service providers also provided protection against natural disasters. An IAAS solution could include back-ups and multiple levels of redundancy that could move data to servers across multiple physical locations ("Hurricanes, Water, Earthquakes, and Flares," 2014). SWFWMD would not need their data and management systems concentrated in a single area. This feature protected against small local disasters, as well as the disasters on a large scale that were difficult to protect against.

\section{Disadvantages of IAAS}

A significant disadvantage of implementing IAAS was the issue of systems integration. The current technology environment of collecting data from multiple input points and data partner sources, storing the data, and processing the models was optimized for the current PC and onsite server system. Changing to IAAS required an overhaul of the current technology environment. Another concern of Dr. Dicks was the possibility that the cloud service provider might go out of business which could mean the loss of access to and/or control over SWFWMD data. In considering this option, he recalled a recent business closing of cloud service vendors, and the difficulty of retrieving data from defunct businesses. A cloud service vendor could have many years of data, and the loss or unavailability of that data could have devastating effects.

One of Dr. Dicks most important concerns related to user adoptability. As systems, policies, and procedures changed, scientists and other SWFWMD employees would naturally push back, as happens in all organizations. Recent research showed that when implementing cloud based technology and solutions within an organization, only about one quarter of employees adopted the technology successfully (Henkes, 2012).

\section{IAAS vs. Onsite Server Cost: Advantage or Disadvantage?}

In considering the cost of cloud service, it was perhaps best to compare it to the cost of onsite server systems, since the technologies were comparable. Dr. Dicks was rightfully concerned with the cost effectiveness of moving to the cloud. An article written by Derrick Wlodarz, on BetaNews.com, detailed various elements that must be considered when analyzing the cost of the two systems. SWFWMD needed to compare and analyze costs associated with power, bandwidth, upgrades, installation and maintenance, software licensing, system downtime, physical and virtual security, and system backups (Wlodarz, 2013). The article performed sample cost calculations for a typical cloud service and onsite server system (see Exhibit 15).

These technology advantages and disadvantages were carefully evaluated, but another challenge must be addressed as well. How effective was knowledge management or EDM in the cloud?

\section{EDM in IAAS Systems}

IAAS could facilitate an EDM strategy, as with an onsite server system, by creating a central location of data storage; but IAAS went one step further. IAAS vendors offered an integrated service package that included data management. This would solve two problems--the problem of growing data processing and accessibility, and the problem of managing the data results of scientific model processing. For Dr. Dicks there were significant challenges in developing a knowledge management or EDM strategy related to data access at the right time and place: data content and navigation, data regulations and copyrights, and data 
access and flexibility (Mason, n.d.). A cloud based EDM solution could address these issues since the knowledge and information would always be available to the users. In addition, IAAS vendors offered customized services that allowed users to specify content and data exploration according to organizational needs.

\section{The Decision}

Dr. Dicks knew that the evaluation process of the options needed to include individuals who would be affected by the decision, and would want to be given the opportunity to share their thoughts.

Interdepartmental collaboration and cooperation was important for the successful implementation of the technology upgrades, and the necessary strategy and policy changes that would allow an effective data management system.

Dr. Dicks mentioned on many occasions that "finding the right technology was the easy part, it's addressing the data knowledge management which was the hard part.” Therefore, Dr. Dicks was left pondering the following questions, among many:

- How could the scientist and model developers be convinced that an EDM system was necessary?

- Which technology option would offer the most effective environment for knowledge management?

- Which option would encourage EDM adaptation?

- Would the current data users and model developers be convinced of the new strategy?

- Would they all adopt the best solution without putting the models, the data, the analysis or the public at risk?

\section{Conclusion}

Dr. Dicks and his team needed to evaluate all options for solving current and future challenges to modeling the water needs of the 4.7 million inhabitants in the 16 Florida counties that relied on SWFWMD. The models were a key component of the services offered by SWFWMD, and their growth would continue to create challenges, but the organization's mission could not be achieved without them. Upgrading to new more powerful PCs, new servers, or new cloud services was necessary, and when the decision was finally made, then it would have to been done based on careful evaluation and analysis of the options. 


\section{References}

Barth, P. (2014). The 4 principles of a successful data strategy. Retrieved from http://www.securityplanet.com

Chandras, R. (2011). 10 Tenets of enterprise data management. InformationWeek, Retrieved from http://www.informationweek.com/software/information-management/10-tenets-of-enterprisedata-management/d/d-id/1095935

Data management capability model (DCAM). (2014). Retrieved from http://www.edmcouncil.org/dcam

Henkes, M. (2012) Why don't employees embrace enterprise mobility projects? Cloud Tech News. Retrieved from http://www.cloudcomputing-news.net/news/2012/apr/18/why-dont-employeesembrace-enterprise-mobility-projects/

Hurricanes, water, earthquakes, and flares: How the cloud protects your data from natural disasters. (2014). Retrieved from https://blogs.microsoft.com/work/2014/10/07/hurricanes-waterearthquakes-and-flares-how-the-cloud-protects-your-data-from-naturaldisasters/\#sm.0000z6mftin2nfsspq81g940zm6rl

Loshin, D. (2001). Enterprise knowledge management: The data quality approach. San Diego: Morgan Kaufmann.

Mason, M.K. (n.d.). Knowledge management: The essence of the competitive edge. Retrieved from http://www.moyak.com/papers/knowledge-management.html

Pandey, A., \& Mishra, S. (2014). Moving from traditional data warehouse to enterprise data management: A case study. Issues in Information Systems, 2, 133.

Smith, A. (2007) Data governance best practices - the beginning. EIMInsight, Retrieved from http://www.eiminstitute.org/library/eimi-archives/volume-1-issue-1-march-2007-edition/datagovernance-best-practices-2013-the-beginning

Velte, T., Velte, A., \& Elsenpeter, R. (2009). Upgrading to energy-efficient servers. Retrieved from http://searchitchannel.techtarget.com/feature/Upgrading-to-energy-efficient-servers

Water management districts: Florida DEP. (2014). Retrieved from http://www.dep.state.fl.us/secretary/watman/

Water resources of the United States. (2014) Retrieved from http://www.usgs.gov/water/

Who we are. (2014). Retrieved from http://www.swfwmd.state.fl.us/about/mission/

Wlodarz, D. (2013). Comparing cloud vs on-premise? Six hidden costs people always forget about. BetaNews, Retrieved from http://betanews.com/2013/11/04/comparing-cloud-vs-on-premise-sixhidden-costs-people-always-forget-about/ 


\section{Biographies}

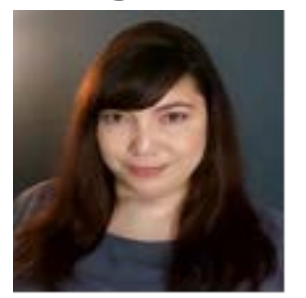

Debbie Bernal earned a Master of Science in Applied Technologies and Entrepreneurship at the University of South Florida and is completing her Master of Business Administration. Selected as a 2014 finalist of the Matthews "Excellence in Intelligence" award, she excels in strategic marketing and competitive intelligence. She has over 10 years of experience in sales and face-toface client servicing, and she works as a staff management consultant for an area engineering firm.

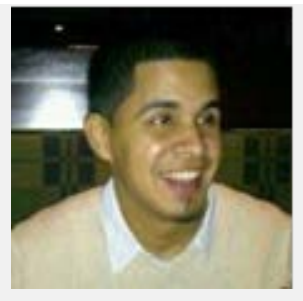

Alex Brito is a part-time Master of Business Administration student, with a concentration in Finance at the University of South Florida. He works full time at PwC, and aspires to reach management level responsibilities within the next five years. With a diverse professional background and employment experience with Fortune 500 Companies, he hopes to continue his professional growth while delivering exceptional service to his employer, customers, and community.

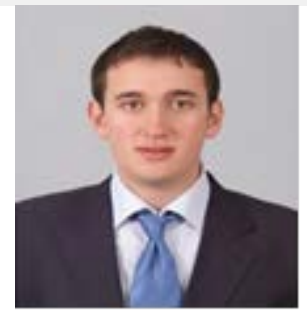

Arda Ergonen is a Master of Business Administration student at the University of South Florida. He earned a Bachelor of Science in Aerospace Engineering at Middle East Technical University in Turkey. He completed aerospace industry internships and worked for two years at Hacettepe University in Turkey as a research assistant in the Mechanical Engineering department. He has experience in tutoring for engineering classes and working on engineering projects. His interests are project management, entrepreneurship, aviation, wind turbines and fluid dynamics. His hobbies are playing chess and listening to music.

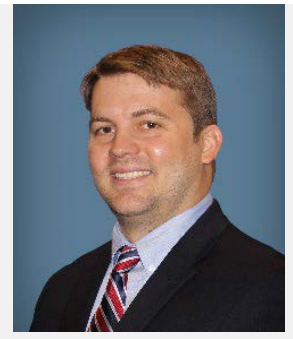

Jay Hoecker is a part-time Master of Business Administration student at the University of South Florida. He earned his Bachelor of Science in Environmental Science and Policy from USF. He works full time as a project manager at the Southwest Florida Water Management District, where he manages the District's Cooperative Funding Initiative program.

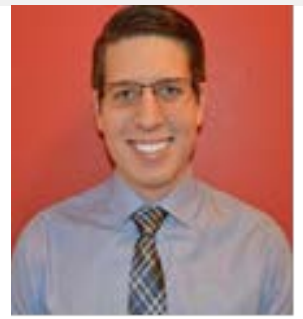

Richard Stiftinger is currently enrolled in the Graduate Certificate in Business Foundations program at the University of South Florida. He earned a Bachelor of Arts in Psychology with a minor in Criminology from USF in 2013. Upon completion of the graduate certificate program, Richard plans to apply for USF's Master of Business Administration program with a concentration in Sports \& Entertainment Management. He previously worked for JPMorgan Chase \& Co. as an operations service delivery representative from 2013-2014. 


\section{Exhibit 1: State of Florida Water Management Districts}

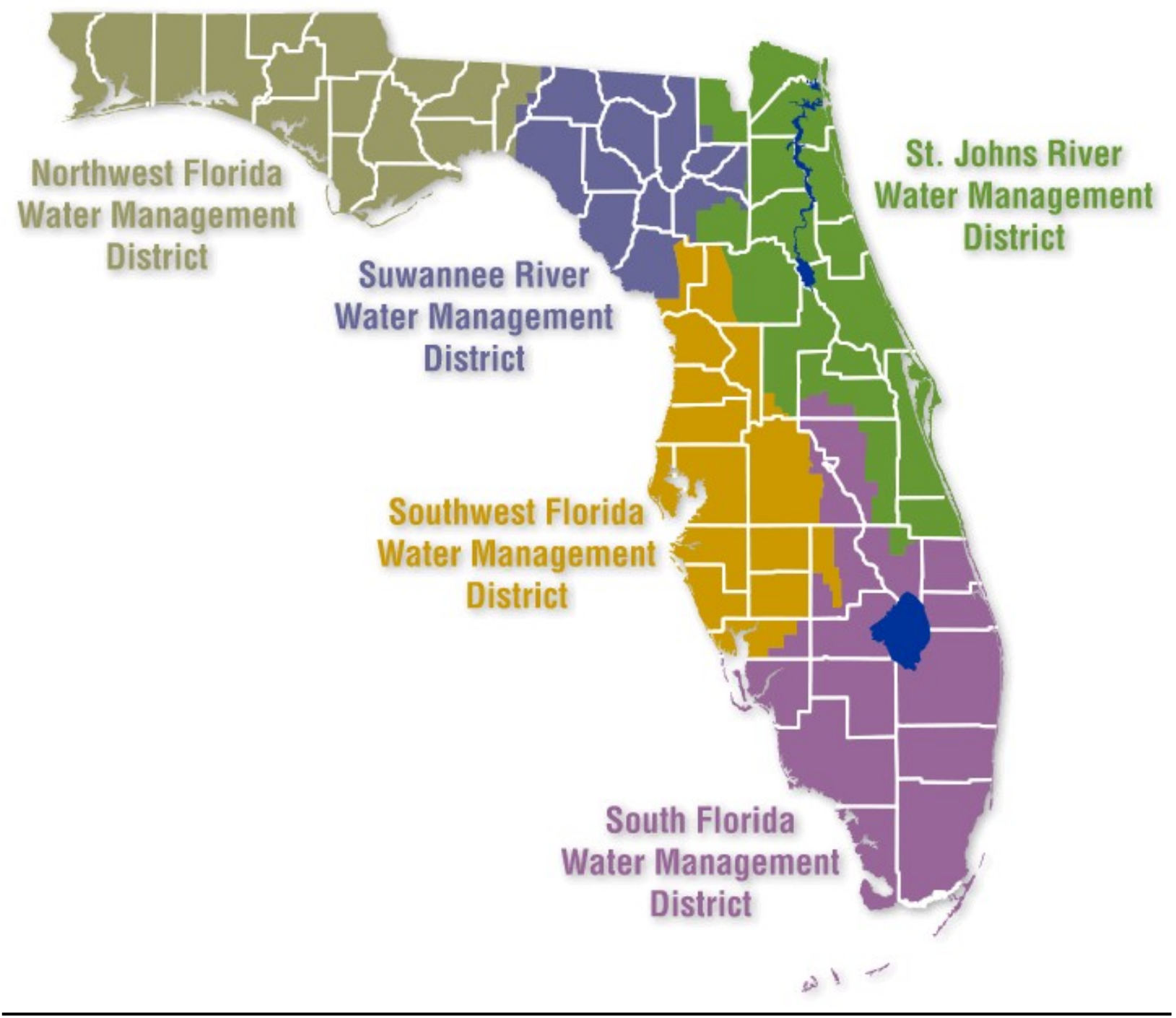

Source: Water management districts: Florida DEP. (2014). Retrieved from http://www.dep.state.fl.us/secretary/watman/ 


\section{Exhibit 2: District Jurisdiction by Florida Counties}

\begin{tabular}{|c|c|c|}
\hline WMD & JURISDICTION & OFFICE \\
\hline Northwest Florida WMD & $\begin{array}{l}\text { Bay, Calhoun, Escambia, Franklin, Gadsden, Gulf, Holmes, } \\
\text { Jackson, Jefferson (western half), Leon, Liberty, Okaloosa, } \\
\text { Santa Rosa, Wakulla, Walton, \& Washington }\end{array}$ & $\begin{array}{l}81 \text { Water Management } \\
\text { Drive Havana, FL } 32333 \\
\text { 850/539-5999 }\end{array}$ \\
\hline Suwannee River WMD & $\begin{array}{l}\text { Columbia, Dixie, Gilchrist, Hamilton, Lafayette, } \\
\text { Madison, Suwannee, Taylor, Union and portions of } \\
\text { Alachua, Baker, Bradford, Jefferson \& Levy }\end{array}$ & $\begin{array}{l}9225 \text { CR } 49 \\
\text { Live Oak, FL } 32060 \\
\text { 386/362-1001 } \\
\text { 800/226-1066 (Florida only) }\end{array}$ \\
\hline St. Johns River WMD & $\begin{array}{l}\text { Brevard, Clay, Duval, Flagler, Indian River, Nassau, Seminole, } \\
\text { St. Johns, Volusia, and portions of Alachua, Baker, Bradford, } \\
\text { Lake, Marion, Okeechobee, Orange, Osceola \& Putnam }\end{array}$ & $\begin{array}{l}\text { P.O. Box } 1429 \\
\text { Palatka, FL 32178- } \\
1429 \text { 386/329-4500 } \\
800 / 451-7106\end{array}$ \\
\hline Southwest Florida WMD & $\begin{array}{l}\text { Citrus, DeSoto, Hardee, Hernando, Hillsborough, Manatee, } \\
\text { Pasco, Pinellas, Sarasota, Sumter, and portions of Charlotte, } \\
\text { Highlands, Lake, Levy, Marion \& Polk }\end{array}$ & $\begin{array}{l}2379 \text { Broad Street } \\
\text { Brooksville, FL 34604- } \\
\text { 6899 352/796-7211 } \\
\text { 800/423-1476 (Florida only) }\end{array}$ \\
\hline South Florida WMD & $\begin{array}{l}\text { Broward, Collier, Dade, Glades, Hendry, Lee, Martin, } \\
\text { Monroe, Palm Beach, St. Lucie, and portions of Charlotte, } \\
\text { Highlands, Okeechobee, Orange, Osceola \& Polk }\end{array}$ & $\begin{array}{l}3301 \text { Gun Club Road } \\
\text { West Palm Beach, FL } \\
\text { 33406- } 3089 \\
\text { 561/686-8800 } \\
\text { 800/432-2045 (Florida only) }\end{array}$ \\
\hline
\end{tabular}

Source: Water management districts: Florida DEP. (2014). Retrieved from http://www.dep.state.fl.us/secretary/watman/ 


\section{Total Workforce \\ (FY2009-10 thru FY2014-15 Adopted)}

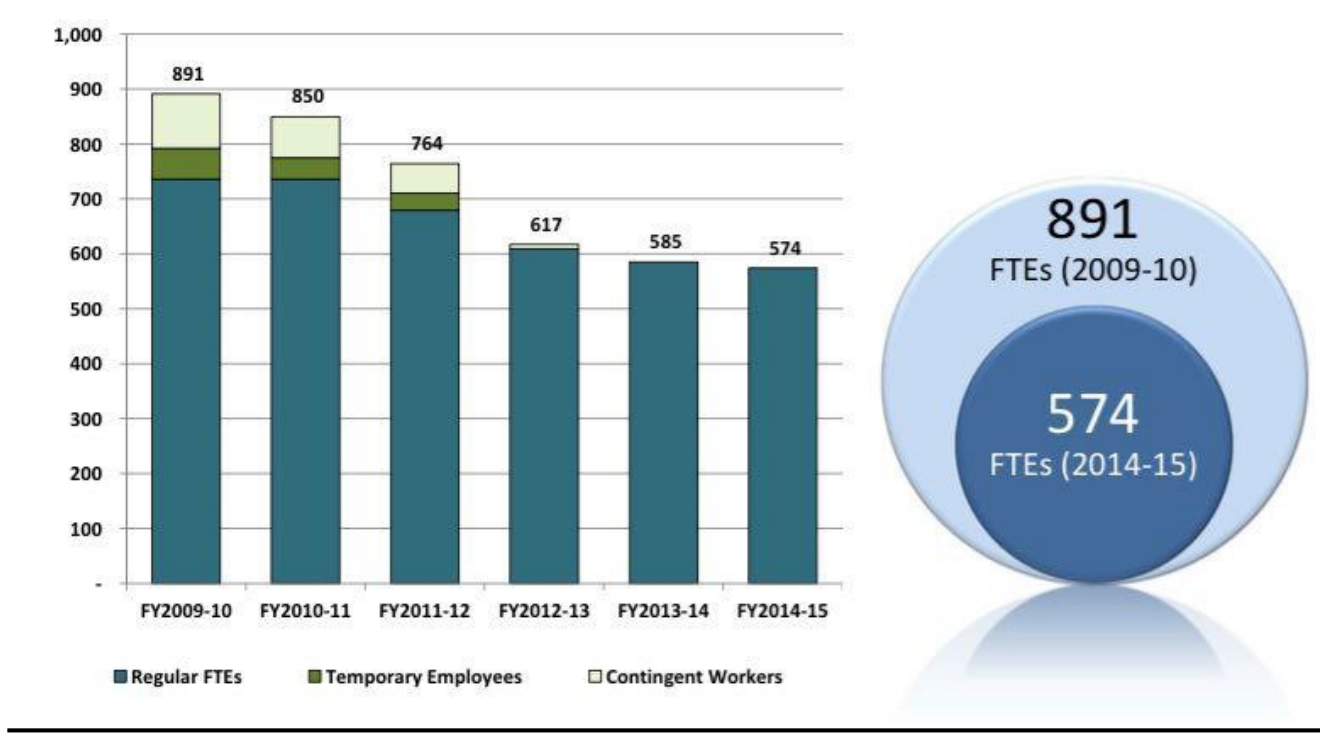

Source: Fiscal year 2014-15 budget-in-brief. (2014). Retrieved from http://www.swfwmd.state.fl.us 


\section{Exhibit 4: How the District was Funded}

FY2014-15 Budget

Ad Valorem Tax Revenue

\begin{tabular}{lr}
$\begin{array}{l}\text { Revenues } \\
\text { (in millions) }\end{array}$ & $\begin{array}{r}\text { Percent } \\
\text { of Total }\end{array}$ \\
\hline$\$ 102.3$ & $61.5 \%$ \\
\hline
\end{tabular}

perty taxes levied on the taxable value of real and personal property as certified by the property appraiser in each county. The millage rate for FY2014-15 is 0.3658 mill, which is the rolled-back rate.

$\begin{array}{lll}\text { State/Federal / Local Funding } & \mathbf{\$ 1 4 . 8} & \mathbf{8 . 9} \%\end{array}$

State funds ( $\$ 13.3$ million) provided by the Department of Environmental Protection, Florida Department of Transportation and Florida Fish and Wildlife Conservation Commission; federal funds $(\$ 85,000)$ provided by the Federal Emergency Management Agency; and local funds ( $\$ 1.5$ million) provided by county/city governments within the District's jurisdiction.

\begin{tabular}{lll}
\hline Other Funding & $\mathbf{\$ 5 . 6}$ & $\mathbf{3 . 3} \%$
\end{tabular}

Various funding sources such as permit and license fees ( $\$ 1.7$ million), interest earnings on investments ( $\$ 3.6$ million), and miscellaneous revenue $(\$ 260,700)$.

$\begin{array}{lll}\text { Balance from Prior Years } & \$ 29.3 & \mathbf{1 7 . 7} \%\end{array}$

Unexpended funds carried forward from the previous fiscal year(s) primarily related to project cancellations and projects completed under budget.

$\begin{array}{lll}\text { Reserves } & \$ 14.3 & \mathbf{8 . 6 \%}\end{array}$

Represents restricted basin reserves of $\$ 10.5$ million and project reserves of $\$ 3.8$ million utilized to fund projects.

\begin{tabular}{lll}
\hline TOTAL REVENUES & $\$ 166.3$ & $100 \%$ \\
\hline
\end{tabular}

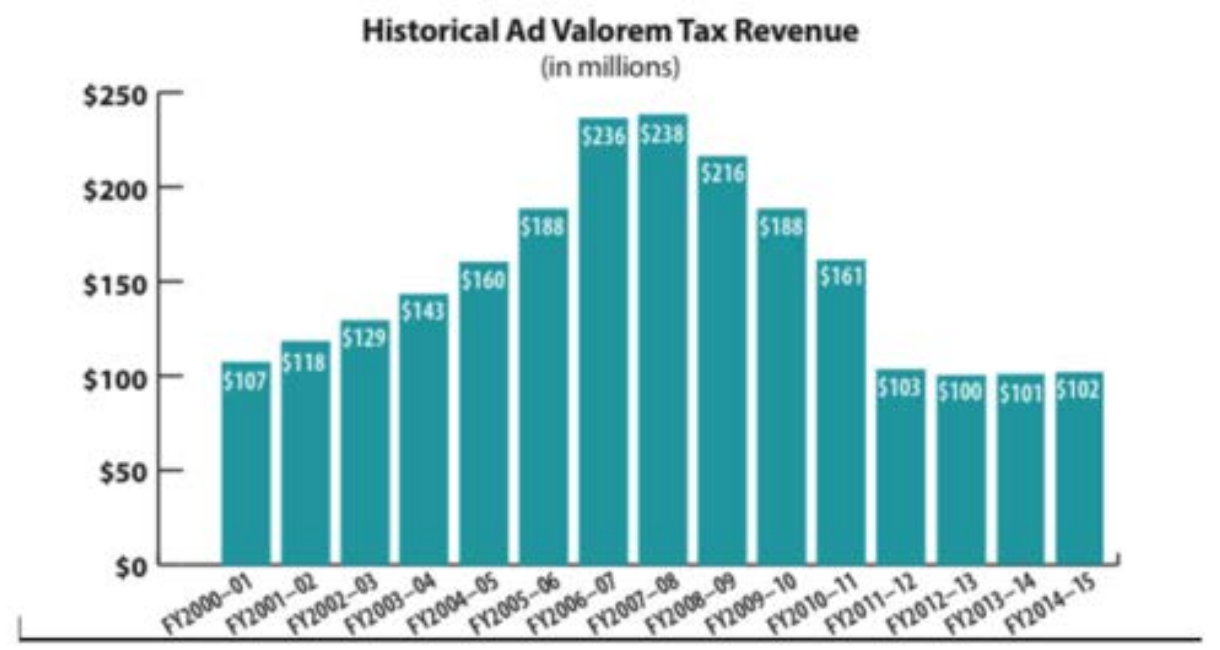

Source: Fiscal year 2014-15 budget-in-brief. (2014). Retrieved from http://www.sfwmd.gov/portal/pls/portal/portal_apps.repository_lib_pkg.repository_browse?p_keywords= budgetprevious\&p thumbnails=no 


\section{Exhibit 5: How the District Allocates Resources by Category}

\begin{tabular}{|lcc|}
\hline FY2014-15 Budget & $\begin{array}{l}\text { Expenditures } \\
\text { (in millions) }\end{array}$ & $\begin{array}{l}\text { Percent } \\
\text { of Total }\end{array}$ \\
\hline Salaries \& Benefits & $\$ 47.4$ & $\mathbf{2 8 . 5 \%}$ \\
\hline
\end{tabular}

Salaries and benefits for District regular full-time equivalent (FTE) positions. The number of FTE positions was reduced from 585 FTEs for FY2013-14 to 574 FTEs for FY2014-15.

Operating Expenses

$\$ 15.9$

$9.6 \%$

This includes items such as Property Tax Commissions, Software/Software Maintenance, Parts and Supplies, Utilities, Insurance and Bonds, Fuels and Lubricants, and Telephone/Data Communications. Reduction of more than $\$ 700,000$ from FY2013-14 through continued cost reductions wherever possible.

\section{Contracted Services for Operational Support \& Maintenance $\quad \$ 8.3 \quad 5.0 \%$}

Outsourced services in support of the District's operations in areas such as information Technology, Data Collection, Land Management, and Structure Operations \& Maintenance.

\section{Operating Capital Outlay \\ $\$ 1.1$ $0.7 \%$}

Purchases of heavy equipment, vehicles, airboats, computer hardware, furniture and equipment with a value per item of at least $\$ 1,000$ and an estimated useful life of one or more years.

\section{$\begin{array}{lll}\text { Cooperative Funding / District Grants } & \$ 76.6 & 46.0 \%\end{array}$}

Matching funds provided through the District Cooperative Funding Initiative, which includes the Water Supply and Resource Development and Cooperative Funding programs and District grants such as the Facilitating Agricultural Resource Management Systems (FARMS) program. The Cooperative Funding Initiative generally provides 50 percent matching funds toward the cost of projects that help create sustainable water resources, enhance conservation efforts, and provide flood protection.

\section{$\begin{array}{lll}\text { Contracted Services for District Projects } & \mathbf{\$ 1 4 . 0} & \mathbf{8 . 4} \%\end{array}$}

District-led projects such as Surface Water Improvement and Management (SWIM) restoration, Institute of Food and Agricultural Sciences (IFAS) Program and Florida Department of Transportation (FDOT) Mitigation. These projects are performed by the private sector and represent direct investments into the economy as well as important projects that protect Florida's water resources.

Fixed Capital Outlay

Funding for land purchases and land improvements, land easements, water control structures, bridges, building and improvements, leasehold improvements and Florida Forever land purchases.

\begin{tabular}{lll}
\hline TOTAL EXPENDITURES & $\$ 166.3$ & $100 \%$ \\
\hline
\end{tabular}

Source: Fiscal year 2014-15 budget-in-brief. (2014). Retrieved from http://www.sfwmd.gov/portal/pls/portal/portal apps.repository lib_pkg.repository browse?p keywords=budgetprevious\&p thumbnails=no 


\title{
Exhibit 6: How the District Allocates Resources by Program Area
}

\begin{tabular}{|c|c|c|}
\hline Y2014-15 Budget & $\begin{array}{l}\text { Expenditures } \\
\text { (in millions) }\end{array}$ & $\begin{array}{l}\text { Percent } \\
\text { of Total }\end{array}$ \\
\hline Water Resources Planning and Monitoring & $\$ 27.3$ & $16.4 \%$ \\
\hline \multicolumn{3}{|c|}{$\begin{array}{l}\text { All water management planning, including water supply planning }(\$ 926,690) \text {, development of } \\
\text { minimum flows and levels for aquifers, lakes and rivers ( } \$ 2 \text { million), and other water resources } \\
\text { planning activities including watershed management planning }(\$ 8.1 \text { million); research, data } \\
\text { collection, analysis, and monitoring ( } \$ 13 \text { million); technical assistance }(\$ 1.2 \text { million) which } \\
\text { includes local/regional plan and program review; and other program activities including } \\
\text { technology and information services. }\end{array}$} \\
\hline
\end{tabular}

Acquisition, Restoration and Public Works $\quad \$ 88.8 \quad 53.4 \%$

All development and construction of capital projects, including water resource and water supply development projects such as reclaimed water, Facilitating Agricultural Resource Management Systems (FARMS), and conservation projects in partnership with local governments ( $\$ 50.8 \mathrm{million})$; surface water projects for the restoration of lands and water bodies with water quality, flood protection and natural systems benefits ( $\$ 33.3$ million); acquisition of land for the protection and management of water resources ( $\$ 3.3$ million); and other program activities including technology and information services.

\begin{abstract}
Operation and Maintenance of Lands and Works $\quad \$ 15.9 \quad 9.6 \%$
All operation and maintenance of flood control and water conservation structures, canals and levees (\$4.4 million); management of public conservation lands, restoring their natural conditions, and providing for compatible recreational use ( $\$ 3.7$ million); Facilities Operation/ Maintenance ( $\$ 3.3$ million); Fleet Services (\$2.2 million); and other program activities including technology and information services.
\end{abstract}

Regulation
All water use permitting ( $\$ 5.5$ million), water well construction permitting and contractor
licensing (\$870,484), environmental resource/surface water management permitting
(\$6.7 million), permit administration/enforcement or any delegated regulatory program
(\$2.3 million); and other program activities including technology and information services.

$\begin{array}{lll}\text { Outreach } & \$ 1.9 & 1.1 \%\end{array}$

All water resources education activities, such as springs protection campaigns and water conservation programs for builders and the hospitality industry $(\$ 813,554)$; public information activities $(\$ 840,972)$; all lobbying activities relating to regional, state and federal governmental affairs; and other program activities including technology and information services.

\begin{tabular}{|c|c|c|}
\hline District Management and Administration & $\$ 12.9$ & $7.8 \%$ \\
\hline \multicolumn{3}{|c|}{$\begin{array}{l}\text { All administrative and operations support ( } \$ 9.4 \text { million or } 5.7 \%) \text {, and commissions to county } \\
\text { tax collectors and property appraisers ( } \$ 3.5 \text { million or } 2.1 \%) \text {. }\end{array}$} \\
\hline TOTAL EXPENDITURES & $\$ 166.3$ & $100 \%$ \\
\hline
\end{tabular}

Source: Fiscal year 2014-15 budget-in-brief. (2014). Retrieved from http://www.sfwmd.gov/portal/pls/portal/portal_apps.repository_lib_pkg.repository_browse?p_keywords= budgetprevious\&p_thumbnails $=$ no 


\section{Exhibit 7: SWFWMD Mission Statement}

\section{Mission}

The mission of the Southwest Florida Water Management District is to manage water and related natural resources to ensure their continued availability while maximizing the benefits to the public. Central to the mission is maintaining the balance between the water needs of current and future users while protecting and maintaining water and related natural resources which provide the District with its existing and future water supply.

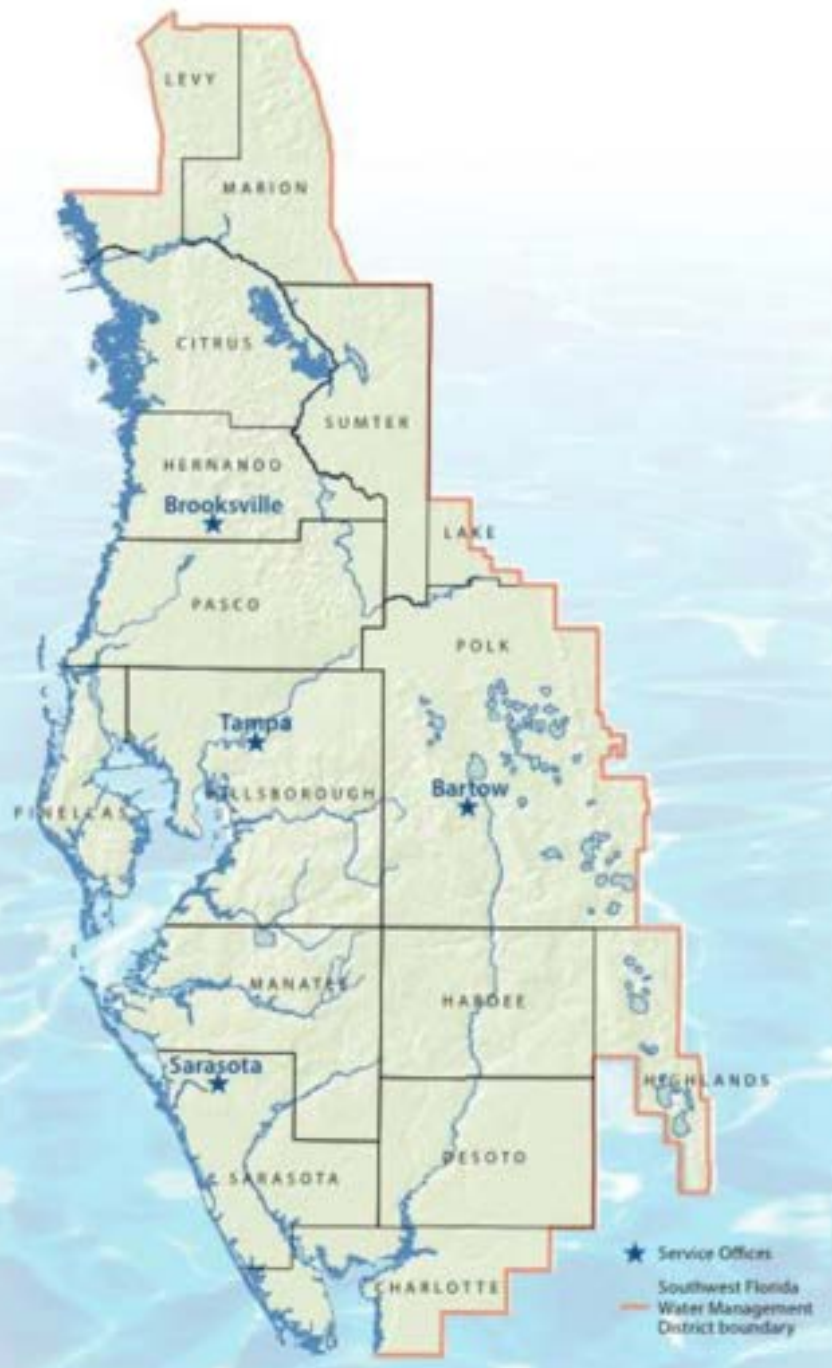

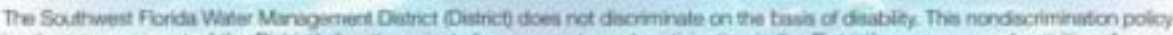

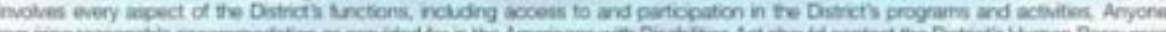

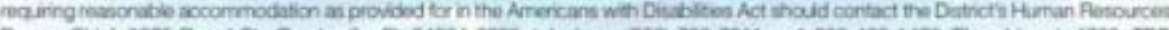

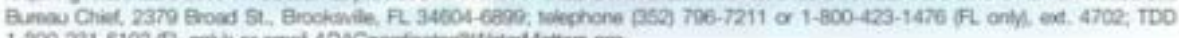

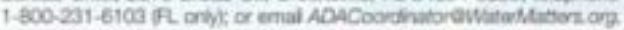

Source: Fiscal year 2014-15 budget-in-brief. (2014). Retrieved from http://www.sfwmd.gov/portal/page/portal/xweb\%20about\%20us/sfwmd\%20about\%20us 


\section{Exhibit 8: SWFWMD Areas of Responsibility (AOR)}

\begin{tabular}{|l|l|}
\hline AOR & Description \\
\hline $\begin{array}{l}\text { Flood } \\
\text { Protection }\end{array}$ & $\begin{array}{l}\text { The District accomplishes flood protection through structural and nonstructural methods. Structural } \\
\text { methods include the operation of 18 flood protection structures. Nonstructural methods include } \\
\text { purchasing lands that store floodwaters, issuing permits to ensure new development does not cause } \\
\text { flooding and contributing funds and technical expertise to local governments for flood protection } \\
\text { programs. }\end{array}$ \\
\hline $\begin{array}{l}\text { Natural } \\
\text { Systems }\end{array}$ & $\begin{array}{l}\text { Protecting water-related natural systems increases the District's ability to carry out all of its } \\
\text { responsibilities. To protect natural systems, the District purchases lands that store floodwaters, secure } \\
\text { future water supply or serve other water-related functions. Additional protection methods include } \\
\text { habitat restoration and the establishment of minimum flows and levels for water bodies. }\end{array}$ \\
\hline $\begin{array}{l}\text { Water } \\
\text { Supply }\end{array}$ & $\begin{array}{l}\text { Ensuring adequate water supplies for people, animals and the environment is central to the District's } \\
\text { mission. The District issues water use permits to ensure withdrawals from water bodies will not harm } \\
\text { existing users, the water resources or the environment. The District also contributes funding and } \\
\text { technical expertise to local governments for programs that conserve water and develop alternative } \\
\text { water supplies. }\end{array}$ \\
\hline $\begin{array}{l}\text { Water } \\
\text { Quality }\end{array}$ & $\begin{array}{l}\text { The District is actively involved in maintaining and improving the water quality within its boundaries. } \\
\text { released. Other water quality activities include various stormwater improvement projects, plugging } \\
\text { abandoned wells and restoration of habitats that naturally filter water. }\end{array}$ \\
\hline
\end{tabular}

Source: Who we are. (2014). Retrieved from http://www.swfwmd.state.fl.us/about/mission/ 


\section{Exhibit 9: Integrated Data Management Features and Advantages}

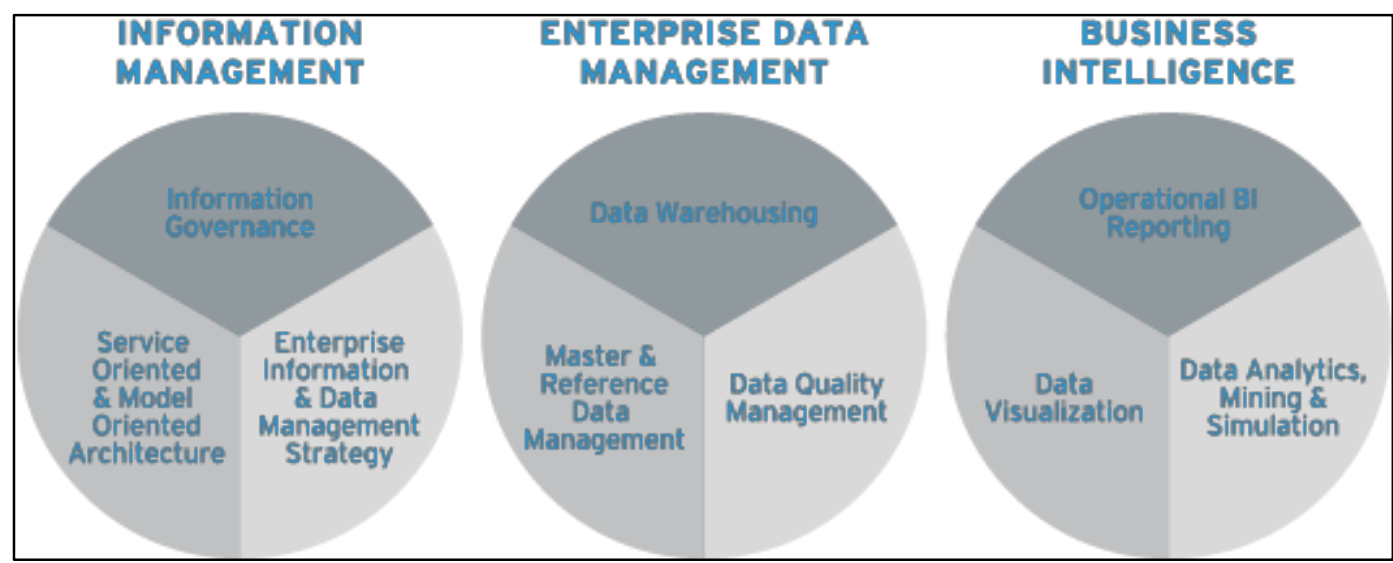

Source: Integrated data management features and advantages. (2014). Retrieved from http://www.genpact.com/ 


\section{Exhibit 10: EDM Offerings}

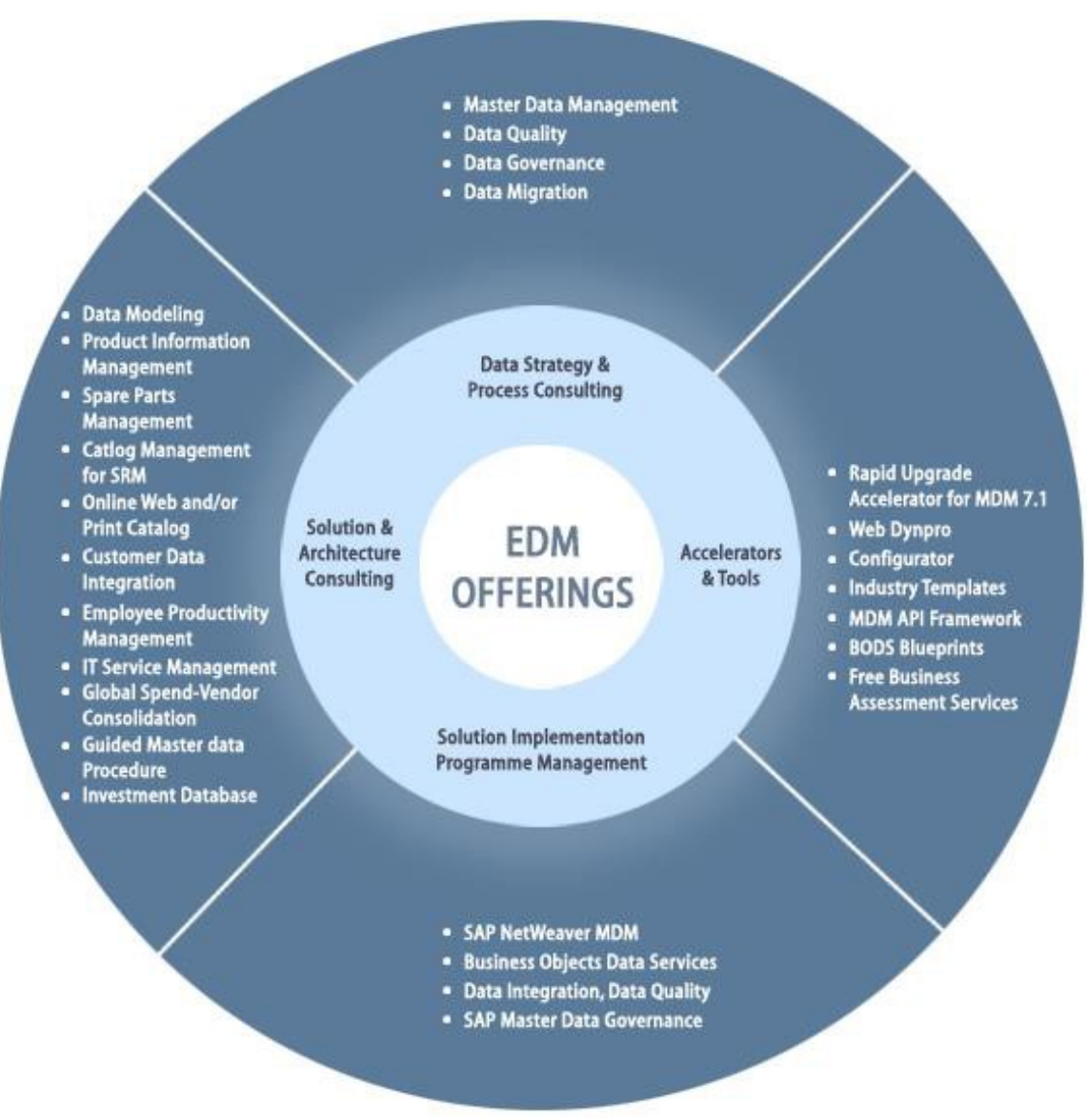

Source: ITC Infotech's enterprise data management service portfolio EDM offerings. (n.d.). Retrieved from http://www.itcinfotech.com/erp/Enterprise-Data-Management.aspx 


\section{Exhibit 11: Onsite Server Cost}

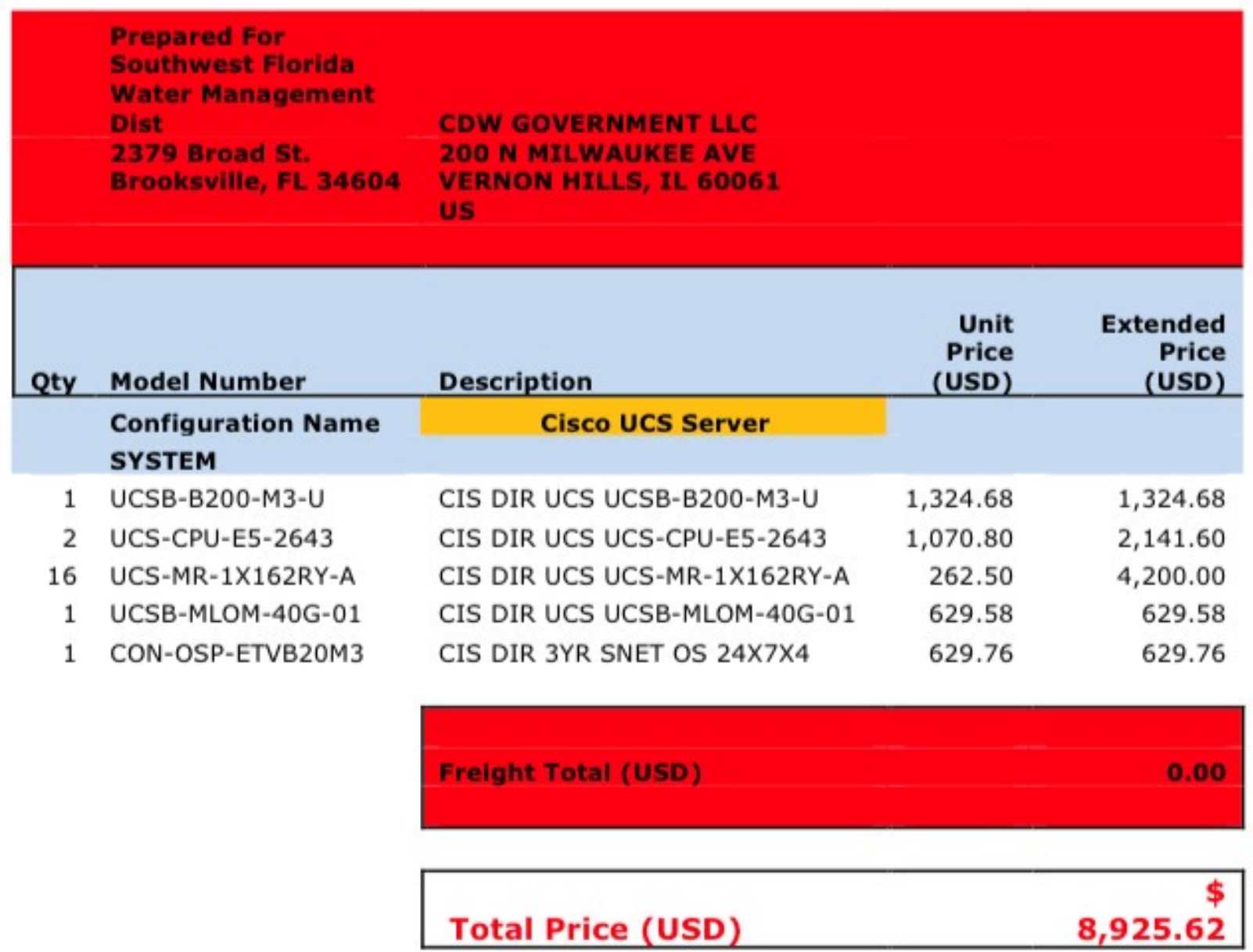

\section{Notes}

Notes:

Total Price is inclusive of Freight Charges (where applicable).

Additional freight charges will be invoiced by CDWG if expedited shipping is requested.

Source: Developed by case writer based on personal communication with Dr. Steven Dicks in 2014 
HOECKER, BERNAL, BRITO, ERGONEN, STIFTINGER

\section{Exhibit 12: Scientific Models and Details}

\begin{tabular}{|c|c|c|c|c|c|}
\hline $\begin{array}{l}\text { SOFTWAR } \\
\text { E NAME }\end{array}$ & $\begin{array}{l}\text { MODEL SOFTWARE } \\
\text { DESCRIPTION }\end{array}$ & $\begin{array}{l}\text { NUMBER OF RUNS } \\
\text { ANNUALLY }\end{array}$ & AVERAGE TIME PER RUN & $\begin{array}{l}\text { INPUT FILE } \\
\text { SIZE PER RUN } \\
\text { (MB) }\end{array}$ & $\begin{array}{l}\text { OUTPUT FILE } \\
\text { SIZE PER RUN } \\
\text { (in MB) } \\
\end{array}$ \\
\hline CHAN & $\begin{array}{l}\text { One-dimensional hydrologic and } \\
\text { hydraulic model }\end{array}$ & 20 & various, normally $<10$ hours & 50 & 1024 \\
\hline DWRM & $\begin{array}{l}\text { Three-dimensional groundwater } \\
\text { simulation system }\end{array}$ & 3000 & $<5$ mins & 50 & 250 \\
\hline ECOMSED & $\begin{array}{l}\text { 3-D hydrodynamic model for } \\
\text { estuarine and shallow water } \\
\text { systems }\end{array}$ & $\begin{array}{c}\text { Depends on } \\
\text { management actions } \\
\text { that may need to be } \\
\text { evaluated }\end{array}$ & $\begin{array}{l}\text { Machine dependent, typically } \\
3-4 \text { days for } 11-y r \text { model run }\end{array}$ & 250 & 40960 \\
\hline EFDC & $\begin{array}{l}\text { 3-D hydrodynamic/ } \\
\text { Thermal Simulation Only }\end{array}$ & $\begin{array}{l}\text { Currently in archive } \\
\text { until re-evaluation }\end{array}$ & $7 \mathrm{hr}$ for 60 day simulation & 8 & 250 \\
\hline EFDC & $\begin{array}{l}\text { 3-D hydrodynamic/ } \\
\text { Thermal Simulation Only }\end{array}$ & Archive & $192 \mathrm{hr}$ for 5 year simulation & 35 & 66560 \\
\hline EFDC & $\begin{array}{l}\text { 3-D hydrodynamic/ Salinity } \\
\text { Thermal Simulation Only }\end{array}$ & & & & \\
\hline $\begin{array}{l}\text { EFDC- } \\
\text { Explorer }\end{array}$ & $\begin{array}{l}\text { 3-D } \\
\text { hydrodynamic/Salinity/Thermal } \\
\text { Thermal Simulation Only }\end{array}$ & $\begin{array}{l}\text { Currently in archive } \\
\text { until re-evaluation }\end{array}$ & 16 hours for $3-y r$ simulation & 11 & 5939.2 \\
\hline $\begin{array}{l}\text { EPA- } \\
\text { SWMM } 5\end{array}$ & $\begin{array}{l}\text { One-dimensional hydrologic and } \\
\text { hydraulic model }\end{array}$ & 30 & various, normally $<10$ hours & 50 & 1024 \\
\hline GeoExpress & Image Processing & 3 & 8 - 10 days/project & 1048576 & 204800 \\
\hline Green-Ampt & $\begin{array}{l}\text { Runoff / infiltration partition } \\
\text { simulator for recharge } \\
\text { estimation }\end{array}$ & 50 & 1 day & 2,000 & 100,000 \\
\hline $\begin{array}{l}\text { Groundwater } \\
\text { r Vistas - } \\
\text { MODFLOW }\end{array}$ & $\begin{array}{c}\text { GUI interface for MODFLOW } \\
\text { and other groundwater modeling } \\
\text { software packages }\end{array}$ & 50 & 1 hour & 400 & 1,500 \\
\hline HCSWMM & $\begin{array}{l}\text { One-dimensional hydrologic and } \\
\text { hydraulic model }\end{array}$ & 30 & various, normally $<5$ hours & 10 & 500 \\
\hline HEC-RAS & $\begin{array}{l}\text { One-dimensional hydraulic } \\
\text { model }\end{array}$ & 100 & Running time is negligible & 5 & 10 \\
\hline $\begin{array}{l}\text { HEC-RAS } \\
\text { v4.1 }\end{array}$ & $\begin{array}{l}\text { One-dimensional river channel } \\
\text { hydraulic simulation model }\end{array}$ & 100 & $\begin{array}{l}\text { less than } 5 \text { minutes for } \\
\text { running one year's simulation }\end{array}$ & 5120 & 5120 \\
\hline $\begin{array}{l}\text { HEC-RAS } \\
\text { v4.1 }\end{array}$ & $\begin{array}{l}\text { One-dimensional river channel } \\
\text { hydraulic simulation model }\end{array}$ & 100 & $\mathrm{NA}^{*}$ & 10240 & 10240 \\
\hline $\begin{array}{l}\text { HEC-RAS } \\
\text { v4.1 }\end{array}$ & $\begin{array}{l}\text { One-dimensional hydraulic } \\
\text { model }\end{array}$ & 100 & Running time is negligible & 5 & 10 \\
\hline HSPF & $\begin{array}{c}\text { Surface Water Model of the } \\
\text { District }\end{array}$ & 20 & $20 \min$ & 50 & 60 \\
\hline ICPR v3 & $\begin{array}{l}\text { One-dimensional hydrologic and } \\
\text { hydraulic model }\end{array}$ & 80 & various, normally $<72$ hours & 200 & 2048 \\
\hline $\begin{array}{l}\text { ICPR v4 } \\
(\text { ICPR2D) }\end{array}$ & $\begin{array}{l}\text { Geo-referenced integrated tow- } \\
\text { dimensional surface and } \\
\text { groundwater capabilities. } \\
\text { Triangular mesh is used for } \\
\text { computational framework and } \\
\text { mesh generation. }\end{array}$ & $\begin{array}{l}\text { depends on changes } \\
\text { in watershed }\end{array}$ & 3 days & 418 & 58368 \\
\hline
\end{tabular}


MUMA CASE REVIEW

\begin{tabular}{|c|c|c|c|c|c|}
\hline $\begin{array}{l}\text { ICPR v4 } \\
\text { (ICPR2D) }\end{array}$ & $\begin{array}{l}\text { Two-dimensional surface water } \\
\text { model with groundwater } \\
\text { capabilities. Includes full } \\
\text { integration of ICPR } \sqrt{3} \\
\text { information and } 2 \mathrm{D} \text { information } \\
\text { (triangular mesh). }\end{array}$ & 100 & $\begin{array}{c}5 \text { days on super computer, } 30 \\
\text { days on current high end } \\
\text { desktops. }\end{array}$ & 76800 & 71680 \\
\hline IHM & $\begin{array}{l}\text { Integrated watershed (HSPF) } \\
\text { and groundwater model } \\
\text { (MODFLOW) }\end{array}$ & $\begin{array}{c}\text { Depends on } \\
\text { management actions } \\
\text { that may need to be } \\
\text { evaluated }\end{array}$ & $\begin{array}{l}\text { Machine dependent, typically } \\
5-6 \text { hours for } 10 \text { yc model run } \\
\text { and } 10 \text { hours for hydrologic } \\
\text { post-processing }\end{array}$ & 1024 & 61440 \\
\hline $\mathrm{IHM}$ & $\begin{array}{l}\text { Integrated surface water / } \\
\text { groundwater model. Links } \\
\text { MODFLOW and HSPF. }\end{array}$ & 20 & 7 hours & 1,000 & 60,000 \\
\hline IMAGINE & Image Processing & depends on WMP & $24-48$ hours & 153600 & 153600 \\
\hline LAMFE & $\begin{array}{l}\text { Laterally average 2D } \\
\text { hydrodynamic model }\end{array}$ & As needed & $\begin{array}{l}3 \text { - } 5 \text { minutes a year on Intel } \\
\text { Quad Core Xeon } 3.2 \mathrm{GHz} \text { PC }\end{array}$ & 100 & 300 \\
\hline LESS & $\begin{array}{l}\text { Dynamically coupled LAMFE } \\
\text { and LESS3D }\end{array}$ & As needed & $\begin{array}{l}120-180 \text { min a yeas on Intel } \\
\text { Quad Core Xeon } 3.2 \mathrm{GHz} \mathrm{PC} \text {, } \\
\text { depending on water body and } \\
\text { domain discretization }\end{array}$ & 1024 & 5120 \\
\hline LESS3D & $\begin{array}{l}\text { Three-dimensional fully } \\
\text { hydrodynamic model (can be } \\
\text { run in hydrostatic or non- } \\
\text { hydrostatic mode) }\end{array}$ & As needed & $\begin{array}{c}30 \text { - } 60 \text { min a yeas on Intel } \\
\text { Quad Core Xeon } 3.2 \mathrm{GHz} \text { PC, } \\
\text { depending on water body and } \\
\text { domain discretization } \\
\text { (hydrostatic mode) }\end{array}$ & 1024 & 5120 \\
\hline LP360 & LiDAR Data Processing & depends on WMP & $24-48$ hours & 307200 & 358400 \\
\hline MARS & LiDAR Data Processing & depends on WMP & $24-48$ hours & 358400 & 358400 \\
\hline MIKE SHE & $\begin{array}{l}\text { Three-dimensional integrated } \\
\text { surface water and groundwater } \\
\text { simulation system }\end{array}$ & 100 & 3 days & 46080 & 10240 \\
\hline MIKE SHE & $\begin{array}{l}\text { Three-dimensional integrated } \\
\text { surface water and groundwater } \\
\text { simulation system }\end{array}$ & 3 & 3 days & 500 & 79872 \\
\hline $\begin{array}{l}\text { MODFLOW- } \\
\text { SURFACT }\end{array}$ & $\begin{array}{l}\text { Northern District Groundwater } \\
\text { Flow Model which runs in } \\
\text { GWVs using the MOOFLOW- } \\
\text { SURFACT code }\end{array}$ & 50 & $15 \mathrm{~min}$ & 100 & 75 \\
\hline MODHMS & $\begin{array}{l}\text { Integrated surface water / } \\
\text { groundwater model. Uses } \\
\text { Groundwater Vistas as interface }\end{array}$ & 200 & 1 hour & 50 & 500 \\
\hline MODHMS & $\begin{array}{l}\text { Integrated surface water / } \\
\text { groundwater model. Uses } \\
\text { Groundwater Vistas as interface }\end{array}$ & 5 & 3 days & 1,000 & 50,000 \\
\hline RCA & 3-D surface water quality model & $\begin{array}{c}\text { Depends on } \\
\text { management actions } \\
\text { that may need to be } \\
\text { evaluated }\end{array}$ & $\begin{array}{l}\text { Machine dependent, typically } \\
12 \text { hours for } 10-y r \text { model run }\end{array}$ & 66560 & 6144 \\
\hline UnLESS & $\begin{array}{l}\text { Dynamic coupling of LAMFE } \\
\text { and UnLESS3D }\end{array}$ & 150 & $\begin{array}{l}300-420 \text { min a yeas on Intel } \\
\text { Quad Core Xeon } 3.2 \mathrm{GHz} \text { PC }\end{array}$ & 2048 & 10240 \\
\hline UnLESS3D & $\begin{array}{l}\text { Three-dimensional unstructured } \\
\text { grid hydrodynamic model }\end{array}$ & 100 & $\begin{array}{l}200-300 \text { min a yeas on Intel } \\
\text { Quad Core Xeon } 3.2 \mathrm{GHz} \text { PC }\end{array}$ & 1024 & 5120 \\
\hline
\end{tabular}

Source: Developed by case writer based on personal communication with Dr. Steven Dicks in 2014 


\section{Exhibit 13: IAAS}

\section{Public IaaS}

Your business rents infrastructure from the cloud provider, and accesses that infrastructure over the Internet, in order to create or use applications.

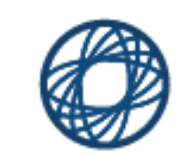

Networking

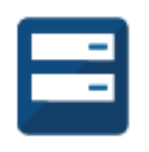

Servers

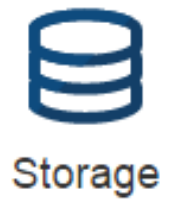

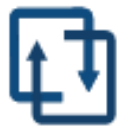

Virtualization

Source: IBM cloud computing: Infrastructure as a service (IaaS). (2014) Retrieved from http://www.ibm.com/cloud-computing/us/en/what-was iaas.html 
Exhibit 14: IAAS Pay-As-You-Go Example Cost Breakdown

\begin{tabular}{lcccc}
\hline INSTANCE & CORES & RAM & DISK SIZES & PRICE \\
\hline A0 & 1 & $0.75 \mathrm{~GB}$ & $20 \mathrm{~GB}$ & $\begin{array}{l}\$ 0.018 / \mathrm{hr} \\
(\sim 13 / \mathrm{mo})\end{array}$ \\
\hline A1 & 1 & $1.75 \mathrm{~GB}$ & $40 \mathrm{~GB}$ & $\begin{array}{l}\$ 0.077 / \mathrm{hr} \\
(\sim \$ 57 / \mathrm{mo})\end{array}$ \\
\hline A2 & 2 & $7.5 \mathrm{~GB}$ & $60 \mathrm{~GB}$ & $\begin{array}{l}\$ 0.154 / \mathrm{hr} \\
(\sim \$ 115 / \mathrm{mo})\end{array}$ \\
\hline A3 & 4 & $7 \mathrm{~GB}$ & $120 \mathrm{~GB}$ & $\begin{array}{l}\$ 0.308 / \mathrm{hr} \\
(\sim \$ 229 / \mathrm{mo})\end{array}$ \\
\hline A4 & 8 & $14 \mathrm{~GB}$ & $240 \mathrm{~GB}$ & $\begin{array}{l}\$ 0.616 / \mathrm{hr} \\
(\sim \$ 458 / \mathrm{mo})\end{array}$ \\
\hline
\end{tabular}

Source: Velte, A. T., Velte, T. J., Elsenpeter, R. C., \& Elsenpeter, R. C. (2009). Upgrading to energyefficient servers. Retrieved from http://searchitchannel.techtarget.com/ 
HOECKER, BERNAL, BRITO, ERGONEN, STIFTINGER

\section{Exhibit 15: Cloud vs Onsite Servers Cost}

\section{On-Premise vs. Software as a Service On-Premise Server vs Azure (L) Cloud Server} Generic Line of Business app sample case

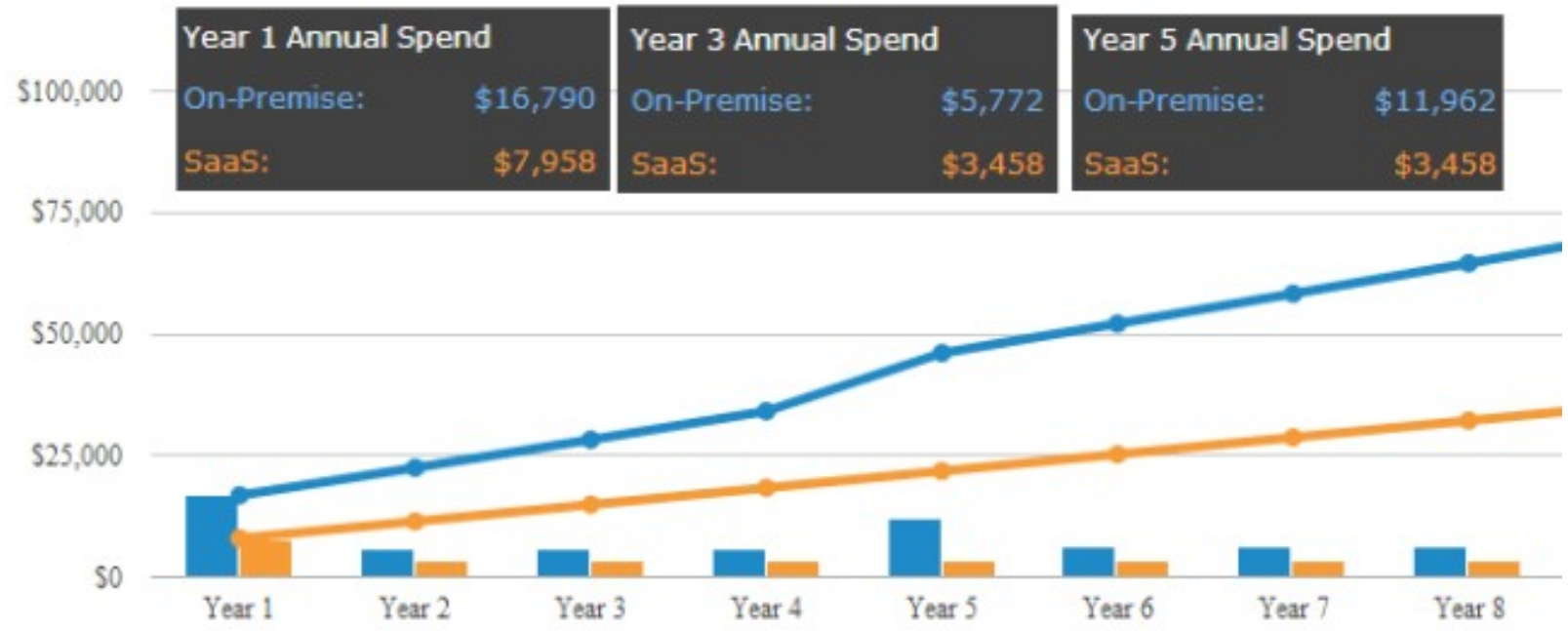

Source: Wlodarz, D. (2013). Comparing cloud vs on-premise? Six hidden costs people always forget about. BetaNews. Retrieved from http://betanews.com/2013/11/04/comparing-cloud-vs-on-premise-sixhidden-costs-people-always-forget-about/ 